\title{
PENENTUAN MUTU CUKA NIRA AREN (Arenga pinnata) BERDASARKAN SNI 01-4371-1996
}

\author{
The Quality Determination of Sugar Palm (Arenga pinnata) Venegar Based on SNI Standard \\ 01-4371-1996
}

Baharuddin, Syahidah, dan Nyni Yatni

\begin{abstract}
This study was aimed to determine quality of sugar palm vinegar (Arenga pinnata) based on SNI 01-43711996. The result was expected to provide material information about the quality of sugar palm vinegar based on SNI 01-4371-1996 and as a reference for further research. Nira of sugar palm as sample used in this research were obtained from Kappang Village, District Cenrana, Maros Regency, South Sulawesi Province. The process of making vinegar through by fermentation of the nira which has been obtained from the field. Vinegar is produced and then tested their quality based on SNI 01-4371-1996. The results showed that the variables that meet the SNI 01-4371-1996 on vinegar fermentation are the liquid form and flavour, acetic acid content, residue of alcohol, $\mathrm{Pb}$ and $\mathrm{Cu}$ metal contamination and arsenic contamination. Variables that not meet the SNI 01-4371-1996 are NaCl, the amount of dissolved solids, test of total sugar, contaminant of metals zinc (Zn) and microbial contamination.
\end{abstract}

Key words: Sugar palm vinegar, Arenga pinnata, nira, SNI 01-4371-1996

\section{PENDAHULUAN}

Degradasi hutan disebabkan oleh beberapa faktor, antara lain adanya pemanfaatan hasil hutan yang tidak terkendali, illegal logging, kebakaran hutan dan perambahan hutan. Sehubungan dengan hal tersebut, telah terjadi pergeseran kebijakan sektor kehutanan dari pengelolaan kayu ke pengelolaan sumberdaya hutan, atau terjadi pergeseran kebijaksanaan dan penekanan orientasi dari aspek ekonomi sematamata ke aspek lingkungan dan sosial. Perubahan kebijaksanaan tersebut, diharapkan dapat mendorong pemanfaatan sumberdaya hutan secara multifungsi dan selanjutnya akan lebih menjamin kelestarian hutan. Dengan demikian hutan tidak hanya berfungsi sebagai penghasil kayu, produk bukan kayu, sumber bahan pangan bagi penduduk, penghasil pakan ternak, penghasil buah-buahan dan tanaman semusim serta dapat memberi manfaat jasa lingkungan dan jasa sosial. Pengembangan sektor kehutanan saat ini selain ditekankan pada pengelolaan hutan berupa kayu juga ditujukan pada pengelolaan hasil hutan bukan kayu. Hasil hutan bukan kayu sudah sejak lama menjadi komponen penting dalam kehidupan penduduk sekitar hutan.
Salah satu tanaman yang banyak tumbuh di dalam hutan adalah aren yang merupakan jenis pohon yang memiliki penggunaan yang luas karena manfaatnya yang banyak mulai dari akar, batang, pelepah, daun sampai pucuk pohon, di samping tandan bunganya yang bisa menghasilkan nira untuk bahan baku dalam pembuatan gula atau pemanis (Lempang dan Soenarno, 1999). Hampir semua bagian fisik pohon ini dapat dimanfaatkan, misalnya akar (obat tradisional dan peralatan), batang (berbagai macam peralatan dan bangunan), daun muda (pengganti kertas rokok). Hasil produksinya juga dapat dimanfaatkan, misalnya buah aren muda (kolang-kaling), air nira (bahan pembuatan gula merah atau cuka), dan pati atau tepung dalam batang sebagai bahan pembuatan aneka makanan dan minuman (Sunanto, 1993). Selain menghasilkan nira, aren dapat pula berfungsi sebagai tanaman konservasi pada lahan miring $(>30 \%)$ dengan populasi tanaman 100-200 pohon/ha (Goldsworthy dan Fisher, 1992). Cuka merupakan salah satu produk yang sudah dikenal sejak lama, selain sebagai produk yang dapat dikonsumsi juga memiliki banyak manfaat bagi masyarakat. Berdasarkan hal tersebut maka perlu dilakukan penelitian tentang mutu cuka yang dibuat dari nira aren. 


\section{BAHAN DAN METODE}

Nira aren yang digunakan dalam penelitian ini diperoleh dari Desa Kappang Kecamatan Cenrana Kabupaten Maros, Propinsi Sulawesi Selatan. Nira yang diperoleh kemudian dimasukkan ke dalam wadah yang tertutup rapat untuk menjaga agar tidak terkontaminasi dengan bakteri atau jamur sebelum proses penelitian dimulai. Setelah sampai di laboratorium, selanjutnya proses pembuatan cuka dimulai dengan cara melakukan fermentasi terhadap nira aren yang telah diperoleh dari lapangan. Cuka yang dihasilkan kemudian diuji mutunya berdasarkan SNI 01-4371-1996 yang meliputi pengujian nilai total asam asetat, $\mathrm{NaCl}$, sisa alkohol, padatan terlarut, total gula, cemaran logam $\mathrm{Pb}, \mathrm{Cu}, \mathrm{Zn}$, cemaran mikroba, dan cemaran arsen (As).

\section{HASIL DAN PEMBAHASAN}

Berdasarkan penelitian yang dilakukan untuk mengetahui mutu cuka nira aren berdasarkan SNI 01-4371-1996, diperoleh hasil sebagaimana yang dicantumkan pada Tabel 1.

Berdasarkan Tabel 1 di atas tampak bahwa variabel yang memenuhi SNI 01-4371-1996 cuka fermentasi adalah keadaan bentuk dan bau, kadar asam asetat, sisa alkohol, cemaran logam $\mathrm{Pb}$ dan $\mathrm{Cu}$ serta cemaran arsen. Cuka dalam pembuatannya melibatkan proses fermentasi alkohol dan fermentasi asam asetat secara berkesinambungan (Syarief, 2009). Berdasarkan penelitian, sebelum pembuatan cuka bahan baku yang digunakan yaitu nira aren tampak sedikit lebih kental namun setelah mengalami proses fermentasi menjadi cuka, bentuknya menjadi encer dan baunya sangat asam.

Pengujian menunjukkan bahwa rata-rata kadar asam asetat cuka nira aren sebesar 7,20\% dan memenuhi SNI 01-4371-1996 tentang cuka fermentasi yang mempersyaratkan kadar asam asetat dalam cuka fermentasi minimal $4 \%$. Asam asetat merupakan komponen utama dari cuka yang merupakan karakteristik khas bagi cuka. Prinsip pembuatan cuka yaitu fermentasi gula-gula sederhana menjadi alkohol dan fermentasi alkohol lebih lanjut menjadi asam asetat. Nira aren segar yang manis itu jika dibiarkan masih tetap di dalam bumbung bambu akan mengalami fermentasi, karena di dalam nira terdapat sel-sel ragi Saccharomyces tuac. Nira yang sudah mengalami fermentasi itu disebut tuak yang mempunyai kadar etanol 4\%. Jika proses fermentasi tersebut dibiarkan berlangsung terus, akan terbentuk asam cuka yang rasanya sangat asam. Cuka aren ini di pasaran masih tetap laku keras untuk bumbu masakan di Jawa, karena tidak menimbulkan sakit perut. Lain halnya dengan cuka sintetik yang lebih pekat itu, sering menimbulkan sakit perut.

Waluyo (1984) mengatakan bahwa pembuatan vinegar atau larutan asam cuka melibatkan dua tahap proses yaitu:

Table 1. Quality of sugar palm vinegar based on SNI 01-4371-1996

\begin{tabular}{|c|c|c|c|c|c|}
\hline No & Test criteria & Unit & Requirements & $\begin{array}{c}\text { Vinegar Test } \\
\text { Results of Sugar } \\
\text { Palm }\end{array}$ & Remarks \\
\hline \multirow[t]{3}{*}{1} & Keadaan : & & & & \\
\hline & - Bentuk & - & Cairan encer & Cairan encer & Memenuhi \\
\hline & - Bau & - & Khas as.asetat & Khas as.asetat & Memenuhi \\
\hline 2 & Kadar asam asetat & $\% \mathrm{~b} / \mathrm{b}$ & Min 4 & 7,20 & Memenuhi \\
\hline 3 & $\mathrm{NaCl}$ & $\% \mathrm{~b} / \mathrm{b}$ & $\operatorname{Min} 30$ & 12 & Tdk memenuhi \\
\hline 4 & Sisa alkohol & $\% \mathrm{~b} / \mathrm{b}$ & Maks 10 & 1,2 & Memenuhi \\
\hline 5 & Padatan terlarut & $\% \mathrm{~b} / \mathrm{b}$ & Maks 1,5 & 2,29 & Tdk memenuhi \\
\hline 6 & Total gula & $\% \mathrm{~b} / \mathrm{b}$ & Min 15 & 1,106 & Tdk memenuhi \\
\hline \multirow[t]{4}{*}{7} & Cemaran logam & & & & \\
\hline & - Timbal $(\mathrm{Pb})$ & $\mathrm{mg} / \mathrm{kg}$ & Maks 1 & 0,16 & Memenuhi \\
\hline & - Tembaga (Cu) & $\mathrm{mg} / \mathrm{kg}$ & Maks 5,0 & 1,54 & Memenuhi \\
\hline & - Seng $(Z n)$ & $\mathrm{mg} / \mathrm{kg}$ & Maks 2,0 & 2,89 & Tdk memenuhi \\
\hline 8 & Cemaran Mikroba & koloni/g & Maks 50 & 262 & Tdk memenuhi \\
\hline 9 & Cemaran Arsen & $\mathrm{mg} / \mathrm{kg}$ & Maks 0,4 & 0,06 & Memenuhi \\
\hline
\end{tabular}


1. Tahap pertama: adalah proses anaerobik yang berlangsung dengan bantuan ragi, biasanya di dalam bahan yang digunakan sudah terdapat ragi secara alami, persamaan reaksi proses tersebut secara sederhana ditulis sebagai berikut :

$$
\begin{aligned}
& \mathrm{C}_{6} \mathrm{H}_{12} \mathrm{O}_{6} \stackrel{\text { yeast }}{2} 2 \mathrm{CH}_{3} \mathrm{CH}_{2} \mathrm{OH}+2 \mathrm{CO}_{2} \\
& \text { glukosa alkohol karbon } \\
& \text { dioksida }
\end{aligned}
$$

2. Tahap kedua: adalah proses oksidasi alkohol menjadi asam asetat, oksidasi tersebut merupakan reaksi aerobik yang berlangsung melalui bakteri asam asetat, persamaan reaksinya adalah:

$$
\begin{gathered}
\text { Bakteri } \\
\mathrm{CH}_{3} \mathrm{CH}_{2} \mathrm{OH}+\mathrm{O}_{2}-\mathrm{CH}_{3} \mathrm{COOH}+\mathrm{H}_{2} \mathrm{O} \\
\text { alkohol oksigen asam asetat air }
\end{gathered}
$$

Setelah fermentasi pembuatan asam asetat berjalan dengan sempurna, tempat penyimpanan harus ditutup dengan baik dan dihindari masuknya oksigen, karena jika terkontaminasi dengan udara, enzim-enzim bakteri asam asetat akan merombak asam asetat sehingga menghasilkan gas karbondioksida dan air (Waluyo, 1984). Menurut Daulay dan Rahman (1992), kriteria mutu vinegar yang utama adalah asam asetatnya, cuka memiliki daya simpan yang lama disebabkan kandungan asetatnya. Sebanyak $0,1 \%$ asam asetat dapat menghambat pertumbuhan bakteri pembentuk spora penyebab keracunan makanan dan 0,3\% asam asetat dapat mencegah kapang penghasil metoksin. Menurut penelitian yang pernah dilakukan "The Vinegar Institute", masa simpan cuka tidak terdefinisikan. Karena kondisinya yang asam, cuka tidak memerlukan bahan pengawet dan penyimpanan pada suhu rendah. "White vinegar" tidak mengalami perubahan selama periode waktu yang lama. Sedangkan cuka jenis lain dapat mengalami perubahan seperti perubahan warna dan adanya endapan, namun produk tersebut masih dapat dikonsumsi (Rismana dan Paryanto, 2007).

Pengujian menunjukkan bahwa rata-rata sisa alkohol cuka nira aren sebesar 1,2\% dan nilai ini memenuhi SNI 01-4371-1996 tentang cuka fermentasi yang mempersyaratkan sisa alkohol cuka fermentasi maksimal 10\%. Cuka yang baik apabila kadar alkoholnya rendah sebab apabila kadar alkoholnya tinggi akan memberikan efek yang kurang baik bagi konsumen juga mengurangi kualitas dari cuka itu sendiri. Hasil pengujian cemaran logam pada cuka menunjukkan nilai masing-masing $\mathrm{Pb}(0,16 \mathrm{mg} / \mathrm{kg}), \mathrm{Cu}(1,54 \mathrm{mg} / \mathrm{kg})$, dan arsen $(0,06 \mathrm{mg} / \mathrm{kg})$ dimana nilai-nilai tersebut memenuhi SNI 01-4371-1996 tentang cuka fermentasi yang mempersyaratkan cemaran logam dalam cuka maksimal $\mathrm{Pb}(1 \mathrm{mg} / \mathrm{kg}), \mathrm{Cu}$ $(5,0 \mathrm{mg} / \mathrm{kg})$ dan arsen $(0,4 \mathrm{mg} / \mathrm{kg})$. Salah satu kandungan mineral dalam cuka adalah tembaga (Cu) yang mempunyai peranan penting bagi manusia berkaitan dengan hemoglobin dimana kekurangan zat tersebut dapat menyebabkan berkurangnya ketahanan tubuh dan memicu meningkatnya kadar kolesterol (Intanwidya, 2005). Sebaliknya dengan timbal $(\mathrm{Pb})$ dan arsen $(\mathrm{As})$ yang juga perlu mendapat perhatian khusus karena merupakan logam yang bersifat toksik (beracun) terhadap manusia (Wikipedia, 2007).

Hasil penelitian juga menunjukkan bahwa masih banyak variabel mutu cuka nira aren yang belum memenuhi SNI 01-4371-1996 tentang cuka fermentasi yaitu $\mathrm{NaCl}$, jumlah padatan terlarut, pengujian total gula, cemaran logam Zn (seng) dan cemaran mikroba. Dari hasil pengujian natrium klorida $(\mathrm{NaCl})$ yang diperoleh sebesar 12 $\%$, dimana nilai ini tidak memenuhi SNI 01-43711996 yang mempersyaratkan $\mathrm{NaCl}$ minimal $30 \%$. Untuk mengatasi hal tersebut dapat dilakukan dengan cara menambahkan garam ke dalam cuka tersebut. Sementara itu nilai rata-rata padatan terlarut dari cuka nira aren sebesar 2,29\%, dimana nilai ini tidak memenuhi SNI 01-4371-1996 yang mempersyaratkan padatan terlarut maksimal $1,5 \%$. Jumlah padatan terlarut yang melebihi SNI diduga disebabkan oleh karena adanya kontaminasi bahan-bahan lain terhadap nira aren yang ditandai dengan kurang jernihnya nira aren yang diperoleh. Dengan demikian, dapat dikatakan bahwa semakin rendah kandungan jumlah padatan terlarut maka semakin bersih nira tersebut.

Selain itu hasil penelitian menunjukkan bahwa total gula yang diperoleh sebesar 1,106\% dan nilai ini tidak memenuhi SNI 01-4371-1996 tentang cuka fermentasi yang mempersyaratkan total gula dalam cuka minimal $15 \%$. Rendahnya total gula pada cuka yang diuji diduga disebabkan oleh karena nira yang mengalami fermentasi memiliki kadar asetat yang tinggi $(7,20 \%)$. Standar mutu total gula salah satunya didasarkan 
pada kandungan gula pereduksi (glukosa dan fruktosa) (Purbaya, 2002). Menurut Varnam dan Shuterland (1994) hal ini dikarenakan selama fermentasi berlangsung terjadi aktivitas khamir yang memecah sukrosa menjadi glukosa dan fruktosa, lebih lanjut menjadi alkohol dan $\mathrm{CO}_{2}$, gula yang termanfaatkan tersebut diubah menjadi alkohol.

Hasil pengujian cemaran logam pada cuka menunjukkan nilai $\mathrm{Zn}$ yaitu $2,89 \mathrm{mg} / \mathrm{kg}$, cemaran logam Zn tidak memenuhi karena dalam SNI 014371-1996 mempersyaratkan maksimal 2,0 $\mathrm{mg} / \mathrm{kg}$. Dari hasil analisis nampak adanya unsur logam dalam cuka, tetapi pencemaran ini jauh lebih rendah dari yang ditentukan SNI 01-43711996, cuka fermentasi. Hal ini didukung oleh pendapat Endang (1991), yang mengatakan bahwa bahan-bahan makanan dari alam seperti susu, daging, air dan bahkan nira juga mungkin tercemar dengan berbagai logam berat. Karena alasan inilah dalam standar kualitas cuka fermentasi SNI 01-4371-1996 disyaratkan harus ada tes bahwa kandungan logam berat tersebut harus di bawah ambang batas yang aman bagi manusia. Kandungan mineral yang ada dalam cuka nira aren, tergantung dari mulai proses penyadapan, pengolahan dan pengemasan cuka tersebut. Sehingga banyaknya logam-logam berat akan menyebabkan cuka berwarna agak gelap (Intanwidya, 2005).

Dari hasil yang diperoleh, cemaran mikroba yang diperoleh sangat tinggi yaitu sebanyak 262 koloni sel mikroba dan tidak memenuhi SNI 014371-1996 tentang cuka fermentasi yang mempersyaratkan cemaran mikroba maksimal 50 koloni/gram. Mikroba yang berperan dalam proses pembuatan cuka adalah khamir dan bakteri, mikroba yang banyak dapat menyebabkan rendahnya mutu bahan baku cuka, ini salah satunya diakibatkan mulai dari proses pemanenan nira sampai proses penelitian yang telah tercemar dan terkontaminasi oleh mikroba. Pertumbuhan mikroba dipengaruhi oleh berbagai faktor lingkungan, di antaranya yaitu suhu, pH, aktivitas air, adanya oksigen dan tersedianya zat makanan (Syamsu, 2005).

Waluyo (1984) mengatakan bahwa asam cuka selain digunakan sebagai bahan penyedap rasa, asam cuka juga banyak digunakan sebagai bahan baku industri untuk memproduksi asamasam alifatis terpenting. Kebanyakan asam cuka juga digunakan sebagai bahan dasar pembuatan anhidrida asam asetat yang sangat diperlukan untuk destilasi, terutama dalam pembuatan selulosa asetat, sebagai pengawet untuk pembuatan obat-obatan (aspirin), pembuatan bahan pewarna (indigo) dan parfum serta disintesa menjadi aseton. Selanjutnya dikatakan bahwa larutan asam cuka yang dibuat secara fermentasi ini mempunyai keunggulan dibandingkan dengan produk asam cuka yang saat ini beredar di pasaran, karena mempunyai flavor yang baik.

\section{KESIMPULAN}

Berdasarkan hasil penelitian, cuka dari nira aren belum memenuhi standar SNI 01-4371-2996 cuka fermentasi. Karena ada beberapa variabel yang menjadi syarat kualitas cuka yang tidak memenuhi standar yaitu $\mathrm{NaCl}$, total gula, cemaran logam seng (Zn) dan cemaran mikroba.

\section{DAFTAR PUSTAKA}

Badan Standarisasi Nasional (BSN). 1996. SNI 01-4371-1996. Cuka Fermentasi. Departemen Perindustrian Republik Indonesia. Jakarta.

Daulay, D dan A. Rahman. 1992. Teknologi Fermentasi Sayur-Sayuran dan BuahBuahan. IPB. Bogor.

Endang. 1991. Kajian Aspek Mutu Merek Nira Enceran Lokal di Pulau Jawa (Thesis). Fakultas Teknologi Pertanian. Institut Pertanian Bogor. Bogor.

Goldsworthy, R., dan Y, Fisher. 1992. Aren Botany and Physiology. CAB International.

Intanwidya, Y. 2005. Analisa Cuka Dari Segi Kandungannya Berikut KhasiatnyaMasingmasing.http://www.mailarchive.com/forum@al umni-akabogor.net/html.[23 Desember 2009].

Lempang, M dan Soenarno. 1999. Mengenal Ragam Fisik Aren. Eboni; Balai Penelitian Kehutanan Ujung Pandang. Makassar.

Purbaya, J. R. 2002. Mengenal dan Memanfaatkan Khasiat Cuka Alami. Pionir Jaya, Bandung. http://www.fajarilmubaru.com . [ 2 Oktober 2009].

Rismana, E. dan I. Paryanto .2007., Beberapa Bahan Pemanis Alternatif yang Aman.http://arengasugar.multiply.com/jou rnal/item/105/BEBERAPA_BAHAN_PEM 
ANIS_ALTERNATIF_YANG_AMAN. [20 Varnam, A.H and J.P Shuterland. 1994. November 2009].

Sunanto, H., 1993. Aren : Budidaya dan Multiguna. Kanisius. Yogyakarta

Syamsu, K., 2005. Mikroba sang Makhluk Halus. IPB. Bogor

Syarief, 2009. Beda Cuka dan Khmar. http://halalsehat.com//journal/item. [14 Januari 2010].

Beverages. Technology, Chemistry and Microbiology. Chapman and Hall. London.

Waluyo, S., 1984. Beberapa Aspek Tentang Pengolahan Vinegar, Dewi Ruci Press. Jakarta.

Wikipedia. 2007. Arsen. http://Wikipedia.org. [28 Juli 2010]

Diterima : 26 November 2008

\section{Baharuddin}

Lab. Keteknikan dan Diversifikasi Produk Hasil Hutan

Fakultas Kehutanan, Universitas Hasanuddin

Kampus Tamalanrea, Jl. Perintis Kemerdekaan Km. 10, Makassar 90245

Telp./Fax. 0411-585917. Indonesia

\section{Syahidah dan Nyni Yatni}

Lab. Sifat Dasar dan Teknologi Kimia Hasil Hutan

Fakultas Kehutanan Universitas Hasanuddin

J. Perintis Kemerdekaan Km. 10 Tamalanrea, Makassar 90245

TIp./Fax. : (0411) 589592

E-Mail: idha_unhas@yahoo.com 